\title{
TOTAL QUALITY MANAGEMENT IN HIGHER EDUCATION AND AN EVALUATION FOR TURKEY
}

\author{
Taner ACUNER \\ Karadeniz Teknik Üniversitesi, İI.I.B.F., İşletme Bölümü, Yardimcı Doçent Dr.
}

\begin{abstract}
Özet: Günümüzde kalite, organizasyonlartn başartstuda çok önemi bir rol oynayan, devrimsel bir kavram olarak nitelendirilmektedir. Toplam Kalite Yönetimi hak ettiği ünü endïstride kazanmus, bunun ardindan hizmet sehtörünün ve dolayıstyla yüksek ögretïn kurumlartntn dikkatini çekmeye başlamş̧tr. Yüksek öğretim kurumlarl, Toplam Kalite Yönetimini geçen yüzyılun başından itibaren kullanmaya başlamışlardır. Bu çalışmada, Toplam Kalite Yönetimi kavramna yönelik genel bir değerlendirme sunulmuştur. Ardundan, tarihsel ve de teorik olarak yüksekogretim kurumlarındaki toplant kalite uygulama girişimleri açıklanmış ve batt Avrupa ve $A B D$ üntversitelerinden konu ile ilgili örnekler verilmiştir. Son olarak, Türkiye'de yïkseköğretimde kalite konusuna değinilmiş ve konu ile ilgill genel bir durum değgerlendirilmesi yapulmuştrr. Toplam Kalite Yönctiminin Türkiye'deki yäksek ögretim kurumlartna uygulanmastna yönelik bazt sorunlar tespit edilmiştit, Bu tespitin ardindan, son olarak, ïlkemizdeki yäksek öğretim kurumlartnda Toplam Kalite Yönetimine ilişkin sorunlara yönelik bazı f̧özäm önerileritte bulunulmuşır.
\end{abstract}

\section{INTODUCTION}

Total Quality Management (TQM) has generally been recognized as a major innovation in management thought and has gained widespread acceptance in business and industry. Many major companies have embraced the concepts of total quality and have these concepts work for them. The benefits of TQM have been outlined in the academic as well as the popular press. As a result, quality is emerging as the central factor for all over the world. One of the most effective strategies to have evolved over the years for improving quality is TQM.

Of course, TQM is not only method for implementing of quality. Also, can be touched to quality control circles (QCC), ISO 9000 series quality management systems and total preventive maintenance (TPM) subjects.

However, among all these concepts, TQM is an evolutionary concept. Its nature, title, role and "acronym designation" are all subject to change with time. It represents current conditions for competitiveness. Organizations who wish to fulfill most, if not all, of the market conditions, will exploit TQM to their advantage by making it a necessary prerequisite for achieving competitiveness, and a means to drive to business rather than just a loose input. TQM is a management philosophy that emphasizes managing the entire organization so that it exceis in all dimensions of its operation. Effective implementation of TQM requires visible leadership and foresight, information technology and staff empowerment. This requires an unflinching pursuit of long term customer satisfaction through the systematic improvement of all products, services and processes [1]. Total quality management relies on soft concepts like leadership, respect, trust and intristic motivation..

With the light of another definition, TQM can be defined as a general management philosophy and set of tools which allow an institution to pursue a definition of quality and means for attaining quality, with quality being a continuous improvement ascertained by customers' contentment with the services they have received [2]. For a successful implementing of TQM, it is needed some main principles such as leadership, commitment, total customer satisfaction, continuous improvement, total involvement, training and education, ownership of problems, reward and recognition, error prevention and teamwork.

Total quality management philosophy in business has been credited with helping to raise morale, reduce costs, improve quality, increase productivity and industrial competitiveness. However some organizations providing intangible services are skeptical about total quality management techniques and the high cost associated with them. Indeed, while proponents say that quality pays, many US firms have abandoned TQM since they don't believe the advantages outweigh the costs. On the other hand, it is believed that total quality management principles and concepts can be very beneficial to higher education [1]. But, it is clear that, there are some difficulties for implementing TQM to 
higher institutions. Moreover, because of implementing way of TQM will be different for each of higher education institutions, it is natural to get different results from each of them. It must not mean it is just a problem of TQM, it is needed to analyze the method of it also. Thing which must be done is able to generate a result which is consistent all of the results.

In this study, it is tried to figure out implementing of TQM to higher education institutions theoretically and historically and then presented some of examples from the world and finally, Turkey's situation in this position is evaluated.

\section{TQM IN HIGHER EDUCATION}

\section{A. Historical Development}

The first attempts to implement TQM in US higher education began in 1985 with two colleges. Them movement spread quickly and in 1990, 78 US higher education institutions were reported to be exploring or attempting to implement TQM [3]. A survey conducted some three years later generated responses from 139 universities and 46 colleges. Of these, 78 percent of universities and 70 percent of colleges were involved in implementing TQM. In a similar survey in 1994, 84 percent of 206 respondents were using some form of quality improvement principles [4].

Advocacy for market accountability and performance assessment has caused the prominent and pervading managerialist culture of the mid 1990's. Late 1970 s has been one of emphasis within the entire education system, on cost effectiveness, performance assessment and the establishment of quality standards. Within the higher education sector, John and Taylor (1990) draw attention to the government's interest in developing a more rigorous set of procedures for evaluating the sector. Those working within higher education organizations since the mid 1980s need hardly be reminded of the push towards and consequent development of a managerialist ideology [5]. The key external changes over the past decade have impinged on the management of higher education and include a reduction in public funding, commensurate encouragement to increase alternative sources of funding, political emphasis on greater market responsiveness and public accountability, tighter coupling between higher education and so called wealth creating needs of society, and a considerable expansion of and access to the system [6].

These strategic drivers have a put premium on: the efficient and disciplined use of resources, the achievement of value for money and increased productivity through the use of systematic planning, organization and control; and on measurement of achievement against declared objectives by comparisons across institutions. In specific terms, the recent statutory changes enacted under, first, the Education Reform Act 1988, and, latterly, the Further and Higher Education legislation of 1992 have reinforced and provided a myriad of challenges. In particular, corporate status has been the catalyst, if not the driving force, for colleges, polytechnics and now the "new universities" to become more businesslike [5]. After ten years from 1992, the higher education sector in the world is facing unprecedented and increasing levels of market accountability precipitated by the legislative processes of subsequent administrations. Linked to their new responsibilities and freedoms management in the incorporated higher education organizations are becoming increasingly " businesslike".

With these developments, there is a prevailing belief that higher education has entered a new environment in which quality plays an increasingly important role. Education quality is probably the most important factor in the competition between countries. Because, quality has a main role at the demand factor, so quality of products and services determined by the way. Education and in particular higher education itself, is also being driven towards commercial competition imposed by economic forces. This competition is the result of the development of global education markets on the one hand, and the reduction of governmental funds that force public organizations to seek other financial sources, on the other. Considering the similarities between experiences encountered in the commercial world and those faced in higher education the phrase "market orientation" is often used to describe the new situation in which a combination of quality and price determines the competitive factors [7].

\section{B. Conceptual Problems in Implementing TQM For Higher Education Institution}

TQM can indeed be applied to higher education institutes but it must be modified to fully recognize some unique aspects of education: namely, that education is a service industry with no visible, tangible "product", per se (as in manufacturing) and that is serves multiple customers [2].

Because of the differences between manufacturing and service industry, some of the problems for implementing $\mathrm{TQM}$ in higher education generate naturally.

For example, higher education is people oriented, even though there are some exceptions such as planning and quality control. In contrast, TQM in the manufacturing is process oriented. 
The emphasis in higher education is on the individual. This represents a difficulty for TQM, since the bulk of advice emanating from the quality movement in industry is that working in teams is central to the successful implementation of a quality assurance strategy [8-10].

Implementing TQM for higher education institutions is different not only being a service industry, but also having a different organizational structure. According to Dew; a university is a rare institution where the faculty has a representative senate. This senate, expresses the faculty's confidence in the university's leadership and expects its voice to be heard in a consensus building process. For these reasons, strategic quality planning in higher education is more democratic than it commonly is in business and within governmental agencies [11].

Some additional negatives come from having a different organizational structure to considering the implementation of TQM might be that defining the students as a customers, and thus allowing them to have what they want, may not necessarily lead the high quality education because there is a huge difference between providing what students want and "education based on informed judgments about individual students needs" [12]. Acknowledging these wants and needs entails defining complicated differences between short term satisfaction and long term gains in education. Along these lines, faculty tend to believe that they know what is the best for the students, because they don't yet realize what they should be learning or need to be learning, so the students should rely directly on the faculty to determine the things that they need to learn. This could be a hindrance because pleasing the customer is the foremost task in implementing and maintaining total quality [2].

The debate on the relevance of TQM approaches in higher education institutions possibly arises because it means different things to different people. At the heart of TQM is a set of beliefs with a number of practical suggestions on its continuity and implementation, with the aim of "getting things right the first time" and thereby maximizing competitiveness and profit. Also, there have been practical suggestions for the implementation of TQM at the faculty level and the institutional level. However, the weight of advice is to exercise caution in its application [13].

Another problems, is about indicators. In the manufacturing sector, performance can be gauged from a relatively small range of indicators. But at the service sector, system is so complex to derive some indicators effectively.

The inputs of an industrial business and a public service higher education institutions are substantially different. Even though an organization, in theory, be broken down and represented by a simple structure, in practice it is definitely complex [14]. In higher education, most assessments are inspections at the end of processes for purposes of ranking and sorting; relatively little diagnostic testing is done. Further, the primary beneficiary is the instructor who uses the results to assign grades, not prevent failures. The key to at least attenuating these problems lies in shifting the primary focus of assessment away from ranking and sorting toward improvement [15].

\section{Basic Models Used In Implementing TQM for Higher Education}

GOAL/QPC, a non-profit Massachusetts- based TQM research company, states that, there are six basic implementation models currently being used [16].

The TQM Element Approach: This approach, used in early 1980s, employ elements of quality improvement programs such as quality circles, statistical process control, quality functional deployment, etc., rather than full implementation of TQM.

The Guru Approach: This approach uses writings of a guru such as Deming, Juran or Crosby, as benchmark to determine what the organization lacks, then uses the guru's systems to make changes. University of Alabama is an example of using benchmarking in implementation of TQM for higher education. Use of Deming's 14-point model is another example.

The Japanese Model Approach: Organizations using this method focused one study of Japanese "Deming prize winners" as a way to develop an implementation master plan. This approach is used by Florida Power and Light.

The Industrial Company Model Approach: In this approach, people visit a US industrial company using TQM, identity its successes, and integrate this information with their own approach. This method was used in the late 1980's by many of the Baldrige National Quality Award winners. For example, Northwest Missouri State University used this method [15].

The Hoshin Planning Approach: This approach developed by a Japanese firm, Bridgestone, was used successfully by Hewlett - Packard . It focuses on successful planning, deployment, execution and monthly diagnosis.

The Baldrige Award Criteria Approach: In this model, an organization uses criteria for the Malcolm Baldrige National Quality Award to identify areas of 
improvement. The criteria cover seven key components of TQM. In 1990s this approach is being used by hundreds of industrial companies.

\section{An Overview of World Universities for Implementing TQM}

Of course, higher education institutions differ in their approach to applying TQM. While, some tried to implement it as a whole and on campus- wide basis, others focused on specific areas or on particular aspects of the total quality philosophy. The diversity is so great that one can pose the question - what is the criterion for calling any improvement program a TQM implementation?

For evaluating the answer of the question, Owlia and Aspinwall made an analysis to investigate different cases in conjunction with the main TQM features. With reference to basic literature on TQM and in particular TQM success factors as well as the criteria proposed by the Malcolm Baldrige National Quality Award, ten factors were found to be critical. They were: Top management commitment, strategic planning, organization for quality, employee involvement and team working, training for quality, design management, process management, supplier quality management, information and analysis, customer focus and satisfaction.

As it is seen on the Graphic.1, training in TQM was one of the first stages taken in almost all cases. Both "customer satisfaction" and "employee involvement and team working" were also adopted in the majority of cases. Accepting students as an important group of customers can be seen as a revolutionary change in the approach to the management of quality in higher education. Top management commitment and establishing an organization for TQM implementation within the institutions happened in around three-quarters of the programs. The features "strategic planning", "design management" and "information and analysis" were approached in a weak majority. Defining processes and trying to improve them was relatively common. The notion of supplier quality management was rare in higher education environment.

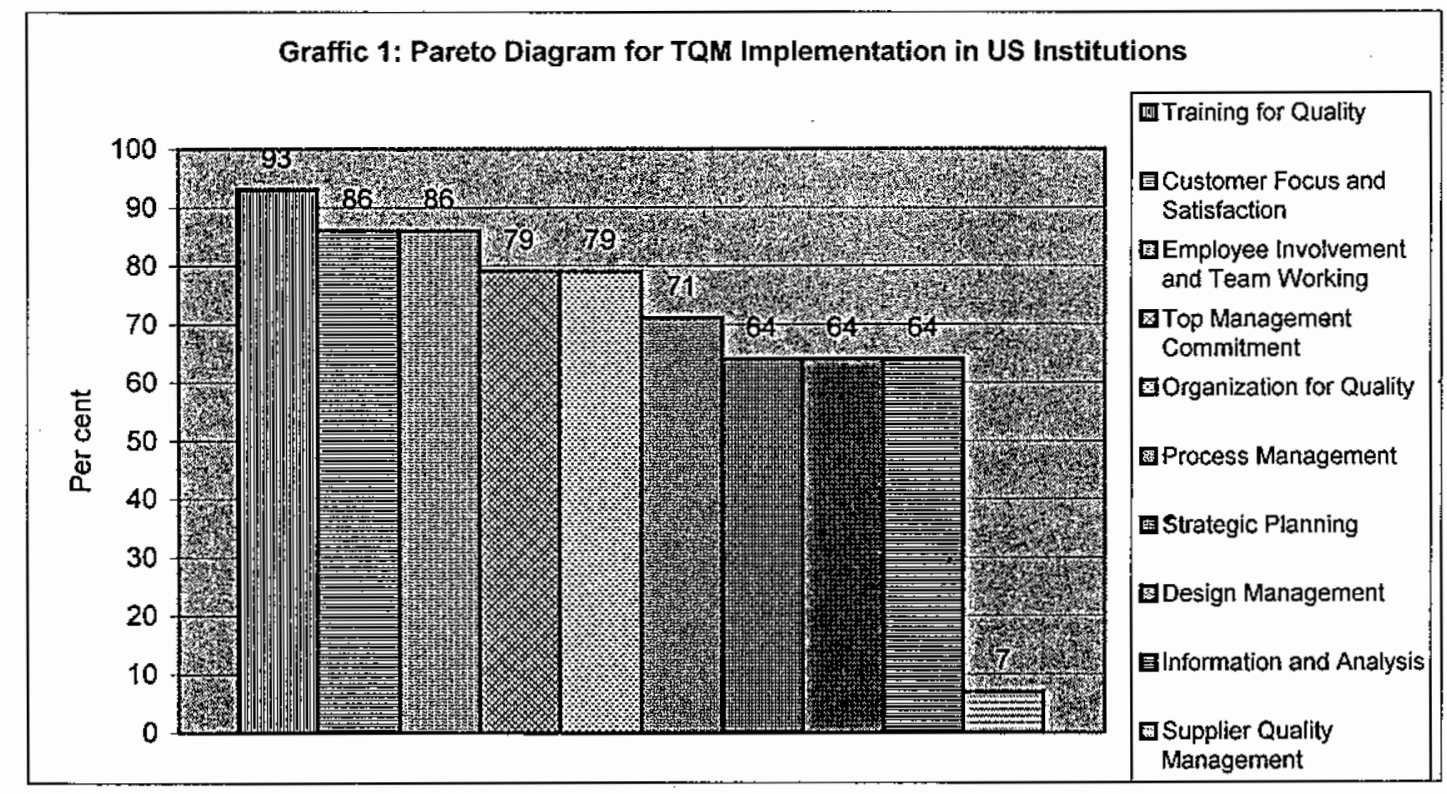

Source : OWVIA, M.; ASPINWALL, E.M., "TQM in Higher Education - A Review", International Journal of Quality \& Reliability Management, Vol.14, No.5, 1997, s.534.

Most programs were reported to be successful. While, these studies were being implemented in the USA, a relatively fewer number of projects were also being undertaken in the UK. It is believed that, While pressure to introduce TQM in the USA came largely from the universities and colleges themselves, in the UK, the government provided the impetus [7]. Also it is said that, UK Universities compared with those in USA, are less inflexible to adapt to the significant changes regarding transformation to a mass higher education system. Competitive forces, however seem to be the ultimate reason for a change in universities' attitude towards new management philosophies like TQM [17].

When the same factors used as an analysis tools in the UK, the graphic below were generated as a part of analysis by Owlia \& Aspinwall. 
As seen at the Graphic 2, employee involvement and team working and process management factors are fully used which are seen rarely in the USA higher institutions. The most frequent factors in the USA, customer focus and satisfaction and training for quality factors have the same percentage with the second rank (\% 83) .Top management commitment and organization for quality factors are less attractive in the UK with \% 67. Strategic planning takes place at the seventh rank with $\% 33$, while it has $\% 64$ at the seventh rank at the USA. Design management and information and analysis are also rare in implementing TQM for higher quality in the UK. There is no institution thinks about supplier and quality management. However, compared to USA cases, it can be seen from the graphic 2 that the less frequent features, i.e. "strategic planning", "design management", "information and analysis", and " supplier quality management" appeared in the same order although all were markedly less frequently adopted in UK cases. Also, the percentage of cases which adopted a specified customer oriented approach is 83 percent, although focus on students as the main customers seemed to be less than in the US studies. The training feature also scored highly with the same frequency. Here again, there was a case which most activities during a four- year program focused on training rather than implementation.

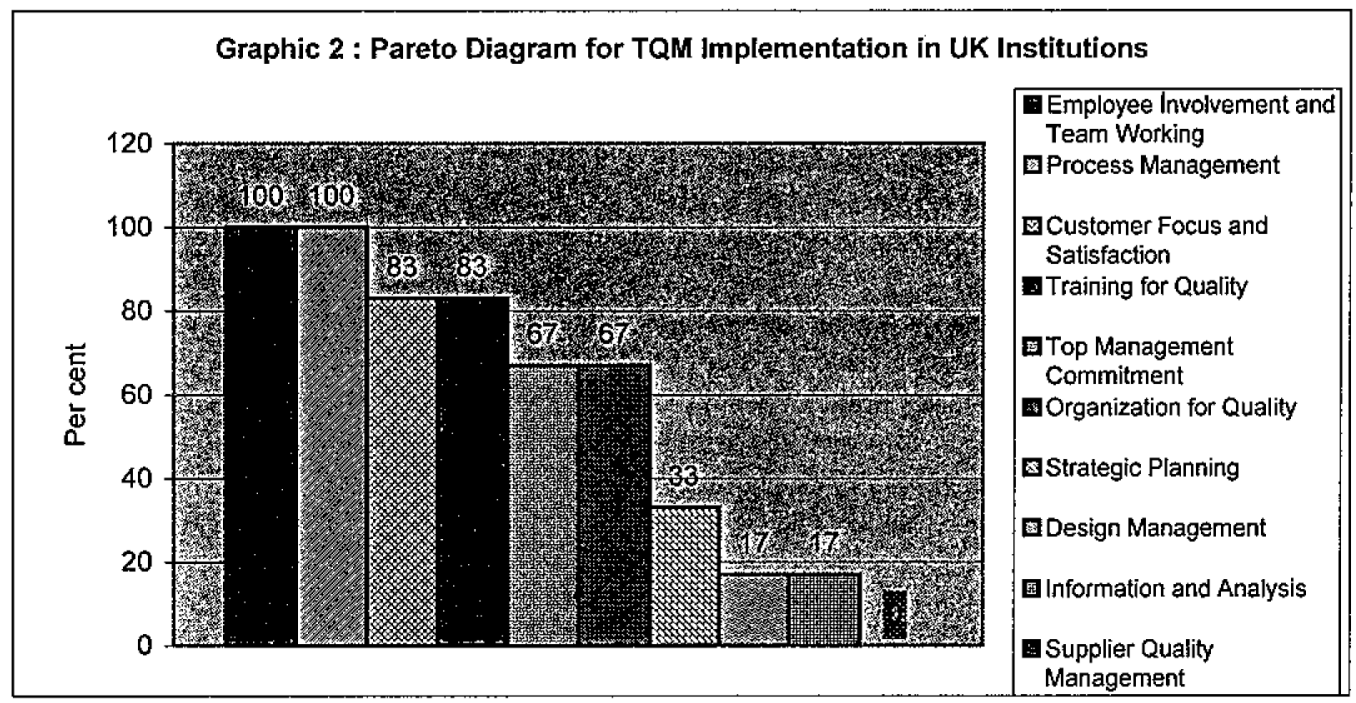

Source: OWLIA, M.; ASPINWALL, E.M., "TQM in Higher Education - A Review", International Journal of Quality \& Reliability Management, Vol.14, No.5, 1997, s.539.

Looking at these results, it can be said that, since most universities were at the early stages of adoption, in the UK, TQM are not implemented for higher education institutions as a whole integrated plan. But, it is clear that, some improvements will have and with today's data, it may get a great improvement already.

\section{E. An Evaluation of Turkish Higher Institutions From the TQM Point of View}

\section{The Need for Quality Assurance Systems in Turkish Higher Education System}

As it is known, from the establish of the republic, there have been some kinds of problems about Turkish Higher Education Institutions in Turkey. There has been a need, felt by government, society, the employment sector and The Turkish Council of Higher Education (Yüksek Ögretim Kurulu, hereafter YÖK), to ensure that, universities are accountable for the resources they consumed. There is a concern that, graduates should have the skills and knowledge to compete with other graduates from all over the world. Every association in the country complains that there is not a real contribution to national prosperity from universities. It is clear that, education in higher education institutes largely depends on repeating and memorization. As a result of this, graduates generally don't have any applicable skills in the business world.

Turkey is a developing country and because of the lack of capital, it is required to use resources in a more productive way. But the situation of higher education institutions in Turkey is completely opposed to country's national aims and plans. According to this aim, Turkish Universities should have an international reputation, particularly within other OECD and EU countries.

As mentioned in the paragraphs above, all slaughters of the society expect higher-quality services from the higher education institutions.

These concerns came at a time of increasing demographic pressure on the Turkish higher education 
system, which (as in other countries) put a strain on sustaining and improving academic standards.

\section{Attempts for Implementing TQM for Turkish Higher Education Institutions}

As a result of pressures mentioned above, YÖK considered that there was a need for a national external quality assessment system to check periodically academic standards, started a pilot project about transfer of a quality assessment system from England. The ofocus of the concern was on evaluations both of research and teaching at subject or program level, with no attention yet to whether an institutional evaluation or accreditation might replace or need to be added to the subject assessments. Turkish universities do not have any form of external quality assessment or institutional accreditation, nor (in common with most other countries) a system of external examiners [18]. Pilot project is evaluated as first step in Turkish Higher Education. Methodology of the pilot project was described by Thomas \& Billing as follows:

The project commenced with an initial workshop for training purposes and to amend documentation requirements to meet the Turkish context. This was attended by representatives of universities and departments that would be assessed, together with those chosen as member of assessment panels. Following submission of documentation by institutions, the assessments took place in October 1997. The process was monitored through analysis of questionnaires issued to institutions, members of assessment panels and the group of UK consultants conducting the project. The findings were discussed at a second workshop held in November 1997. An international conference preceded this workshop. Study tours to France, Holland, the UK and the USA were also arranged. The project concluded with the presentation of a final report at two seminars in held in Ankara in January 1998 attended by members of the YÖK Academic Assessment Board and other key participant.

YÖK, the Turkish Council of Turkish Education, wishes to see the development of an academic assessment mechanism for both teaching and research in Turkish Universities. These processes should be aimed at raising academic standards in the universities, and should be based on departmental self-evaluations for teaching and submissions in agreed formats to expert panels for research. The aim is to link these processes to a new demand-driven formula- funding mechanism for higher education. YÖK wishes firstly to raise awareness of the issue involved in the assessment of teaching and research....and to demonstrate the value of these processes by conducting pilot assessments of both teaching and research, in 13 selected Turkish university departments in late 1997 [19].
Of course, evidence for the effectiveness of the transfer is open the discussion. Not developing but transferring a system caused some kinds of problems naturally. Most systems contain certain assumptions on which their effectiveness relies. In basing the Turkish pilot exercise on the UK's model, it became apparent that certain assumptions applicable to the UK environment were absent in the Turkish context. For example, there was no system of external examiners in Turkey, yet the UK's quality assurance model for teaching assessment incorporates external examiners' reports as an integral part of internal arrangements for the maintenance of standards and assumes that these reports can be seen by visiting assessment teams. Nor does Turkey have professional bodies that influence curriculum design or the form of examination. There is therefore no source of external, objective specialist comment on programs, student assessment arrangements or output standards. There were two consequences, a range of material available in the UK knowledge that there were no other external benchmarking processes or checks on the validity of student assessment. Examples can be increased. As a consequence, to have a progress, the model transferred to Turkey will need further modification for Turkish conditions. However, it can be said that it provided an appropriate basis for development.

After this first step, TQM concept became more well known concept and some of the researchers conducted some researches about it. One of the most wide of the researches is conducted by Başkent Üniversitesi. Başkent Üniversitesi started efforts about "Quality in Education" in 1997 and applied Türk Standartları Enstitüsü (Turkish Standard Institution, TSE) and took TS-EN ISO 9001 Quality System Paper given by TSE. After taking this paper, conducted a research about not only academic but also management staff involved in efforts of quality in education in order to get their commitments. Used in questionnaire method and Pearson chi-square test were applied to finding with SPSS program in $\% 5$ trust level.

According to population, the most difficult elements of the efforts about quality in higher education are: Not being an example model (\%32), bad timing (\%18), insufficient time span (\%16), insufficient personnel and not having enough knowledge (\%12), bad organizing and lack of motivation (\%10). Same population described the easiest elements of the efforts about quality in higher education as follows : High motivation level of the quality team $(\% 20)$, approach of team coordinator about making easy ( $\% 16)$, usefulness of inside courses (\%16), being easy writing of procedures and job descriptions and recording quality notes (\%16), already had been doing some of the jobs took place in the procedure (\%14), ease of criticism in meetings (\%6). 6 percent of the population answered this question such "there is no easy element to apply". Joining to research 
rate of academic personnel was lower than expected. Another interesting point is that, preferring not to choose any answer to "what is the worst element of the effort about TQM in higher education system" by managerial (supportive) personnel [20].

All of these findings could be seen that total quality management in higher education institutions are started. But, "bad timing" excuse, low participation rate of academic personnel for a better TQM model, avoiding from answering some questions by managerial (supportive) personnel and especially "we have been making these works already" answers of the academic personnel shows that TQM concept do not have a strong basis yet.

Approach to concepts reminds some kinds of structural problems, for example "we have been making these works already" answer could indicate any hopeless of academic personnel about organizational structure? Or managerial (supportive) personnel's avoiding from answer some kinds of questions could be a result of fear from the top management? In order to bring to the light these questions, it should be looked at YÖK from feasibility of applying TQM to Turkish higher education point of the view.

In Turkey, it could be said that it should be discussed how to Turkish higher education system wholly or each of universities privately can get a better situation and in order to reach that goal, what kinds of tools such as law, social environment, organizational structure could improve. All of these elements are out of the aim of this study. However, it is almost impossible to neglect direct effects of these situation to Turkish higher education institutions.

It is possible to see some progress in Turkey higher education institutions, however, at the same time, there are some problems related with low quality levels of education and research. Curriculums are not able to be in consistent with the requirements of the modern world. Wage level of personnel is so far away from optimal. With these realities, it has becoming more difficult to find academic personnel who has enough skills. The problems of students such as economical and social is another subject to discuss. Also, it proper to discuss the fund the fund used by universities. There is no any external inspection about universities spending. But, as it is known, they use government resources and in consistent with the "accountability principle" universities should be audited. After auditing, it should be determined the share which university deserves from the fund of government. In this way, it could be possible to use government funds based "service quality". It will make universities more competitive. With opening new foundation universities also, universities are becoming more competitive. Starting promoting themselves with brochures, fair, websites and other tools by universities shows that reality. Another subject is about "scientific autonomy" and " democratic structure". These two principles should be tried keeping in every university.

All of these difficulties mentioned above are make applying TQM to higher education system more difficult. If tried to categorize these reasons, Yağı's's categorization could be presented [21]. According to Yağlz, there are three kinds of problems about applying TQM for Turkish higher education institutions: Reasons welded law, reasons welded lack of resource and reasons welded behaviors.

Reason welded law is related with 2547 .YÖK law and regulations originated with this law. This law can hinder generating a democratic university environment sometimes. Organizational structure cannot differentiate from one university to another. And sometimes promotion of the academic personnel can be based some quantitative criterion and this can be cause to decreasing quality level.

Reasons welded lack of resources is another subject to prevent quality applications. It is difficult to get a higher wages level. It causes some difficulties about attract and keep qualified people at the universities. To provide required tools for higher education is sometimes impossible. Supportive funds for research are also so limited.

Reasons welded behavior are more qualitative and related with the minds of academic and supportive personnel: Academic personnel don't have a strong cognitive level about continuous progress and quality. Resisting to any external evaluation shows that best. They also resist to evaluating by students also. Because of their job description, they don't see the institution's success as important as their success. This idea structure cause lots of problems related with the quality.

\section{CONCLUSIONS}

When looked at global implications of TQM for higher education institutions, some of the characteristics could be seen. First of all, quality is identified as a strategic goal and accepted as a life style. Top management are informed well about TQM and they undertake a motivating role. All units of the university adopt "customer" and "customer satisfaction" concepts. Finally, process in a long run system rather than a problem solving tool in the short run.

In that perspective, Turkish Universities have to improve themselves. Quality Associations in the country can play a vital role in this process. Associations like Türk Standartları Enstitüsü (Turkish Standards 
Institution), KALDER (Quality Association) may come together to create a cooperative work to make "quality" concept wider.

But, YÖK should not present a TQM model for every university. It not only cause not able to differentiate, but also is completely opposed to "quality philosophy". YÖK may set universities free in any attempts, also should give permission them for any cooperative implication.

Higher education institutions are responsible for offering required qualified services by using resources, which is offered them by government, sufficiently. However, there are lots of problems about quality. Some of the problems are welded by law and lack of capital. But most important problems are welded human behaviors and processes. In Turkish universities, most important condition for success of a TQM model, radical change on behaviors of whole personnel. For that radical change three elements are needed: customer focus, full participation and continuous improvement. When these three elements come together to create a radical change then top management should start implication details of strategic plan.

\section{References}

[1] ELMUTI, D.; KATHAWALA, Y.; MANIPPALLIL, M., "Are Total Quality Management in Higher Education Worth the Effort?", International Journal of Quality \& Reliability Management, Vol.13, No.6, 1995, ss.29-44.

[2] MICHAEL, R.; SOWER, E.; MOTWANI, J., "A Comprehensive Model for Implementing Total Quality Management in Higher Education", Benchmarking for Quality Management \& Technology, Vol.4, No.2, 1997, ss. 104-120.

[3] COATE, L.E., "The Introduction of Total Quality Management at Oregon State University", Higher Education, Vol.25, No.3, 1993, ss.303-320.

[4] OWLIA, M.; ASPINWALL, E.M., "TQM in Higher Education - A Review", International Journal of Quality \& Reliability Management, Vol.14, No.5, 1997, ss.527543.

[5] HOLMES, G.; McELWEE, G., "Total Quality Management in Higher Education: How to Approach Human Resource Management?", The TQM Magazine, Vol.7, No.6, 1995, ss.5-10.

[6] MIDDLEHURST, R.; ELTON, L., "Leadership and Management in Higher Education: The Moderating Influence on Contextual Variables", Studies in Higher Education, Vol.17, No.3, $1992 .$.
[7] WILLIAMS, G., "Total Quality Management in Higher Education: Panacea or Placebo", Higher Education, Vol.25, No.3, 1993, ss.229-237.

[8] CROSBY, P., Quality is Free: The Art of Making Quality Certain, McGraw-Hill, New York, 1979.

[9] DEMNG, W.E., Out of the Crisis, Cambridge University Press, Cambridge, 1982.

[10] JURAN, J.M., Quality Control Handbook, McGraw-Hill, New York, 1962.

[11] DEW, J.R., "Roll Quality Roll", Quality Progress, September 2000, ss.49-54.

[12] CHICKERING, A.W.; POTTER, D., "TQM and Quality Education: Fast Food or Fitness Center?", Educational Record, Vol.74, No.2, 1993, ss.35-36.

[13] ROFFE, M.I., "Conceptual Problems of Continuous Quality Improvement and Innovation in Higher Education", Quality Assurance in Education, Vol.6, No.2, ss.74-82.

[14] SILVERMAN, D., The Theory of Organizations, Heinemann, London, 1970. [16] COATE, L.E."TQM at Oregon State University", Journal for Quality and Participation, December 1990, ss.90-101.

[15] HUBBARD, D.L., "Can Higher Education Learn from Factories?", Quality Progress, Vol.27, No.5, 1994, ss.9397.

[16] COATE, L.E., "TQM at Oregon State University", Journal for Quality and Participation, December 1990, ss.90-101.

[17] ERIKSEN, S.D., "TQM and the Transformation from an Elite to a Mass System of Higher Education in the UK", Quality Assurance in Education, Vol.3, No.1, 1995, ss.14-29.

[18] BILLING, D.; THOMAS, H. "The International Transferability of Quality Assessment Systems for Higher Education: The Turkish Experience", Quality in Higher Education, Vol.6, No.1, 2000, ss.31-39.

[19] BILLING, D., "The Feasibility of Establishing a System of Quality Assurance in Universities in Turkey", Unpublished Project Report, Manchester, British Council, 1998.

[20] AKŞIT, B.T.; GÜRAY, S.., "Yüksek Eğitim ve Öğretimde Sürekli Kalite Iyileştirme", Önce Kalite Dergisi, Y11:6, Say1:8, 1998, ss.38-44.

[21] YAĞIZ, Ö., "Yăkseköğretim Kurumları ve Toplam Kalite Yönetimi", ODTỦ Gelişme Dergisi, Cilt.24, Sayı.2, 1997, ss.257-29 